\title{
Stability of $\mathrm{CaCO}_{3}$ in $\mathrm{Ca}(\mathrm{OH})_{2}$ solution
}

\author{
Sevgi Kilic, Gorkem Toprak, Ekrem Ozdemir* \\ Department of Chemical Engineering, Izmir Institute of Technology, Gulbahce Campus, Urla, Izmir, Turkey
}

\section{A R T I C L E I N F O}

\section{Article history:}

Received 26 May 2015

Received in revised form 29 October 2015

Accepted 14 December 2015

Available online 17 December 2015

\section{Keywords:}

Nano

$\mathrm{CaCO}_{3}$

$\mathrm{Ca}(\mathrm{OH})_{2}$

Stability

Zeta

Potential

\begin{abstract}
A B S T R A C T
The effect of calcium hydroxide $\left(\mathrm{Ca}(\mathrm{OH})_{2}\right)$ on the stability of calcium carbonate $\left(\mathrm{CaCO}_{3}\right)$ particles was investigated with respect to the surface potential and particle size. Both $\mathrm{CaCO}_{3}$ and $\mathrm{Ca}(\mathrm{OH})_{2}$ were dissolved in ultrapure water at concentrations up to $100 \mathrm{mM}$. The solubility limits were about $18 \mathrm{mM}$ for $\mathrm{Ca}(\mathrm{OH})_{2}$ and about $0.13 \mathrm{mM}$ for $\mathrm{CaCO}_{3}$ at $23^{\circ} \mathrm{C}$ in water. Dissolution of commercial $\mathrm{CaCO}_{3}$ in $10 \mathrm{mM}$ of $\mathrm{Ca}(\mathrm{OH})_{2}$ solution and dissolution of $\mathrm{Ca}(\mathrm{OH})_{2}$ in $10 \mathrm{mM}$ of $\mathrm{CaCO}_{3}$ slurry were also studied at similar conditions. Conductivity, $\mathrm{pH}$, zeta potential, and average particle sizes were measured for each solution. The morphological characteristics of the particles were analyzed by the SEM images. It was found that the zeta potential of $\mathrm{CaCO}_{3}$ particles was greater than $+30 \mathrm{mV}$ when they were placed in the $\mathrm{Ca}(\mathrm{OH})_{2}$ solution compared to a zeta potential value of $-10 \mathrm{mV}$ in water. It was concluded that the $\mathrm{Ca}(\mathrm{OH})_{2}$ solution is a stabilizer for the $\mathrm{CaCO}_{3}$ particles.
\end{abstract}

(c) 2015 Elsevier B.V. All rights reserved.

\section{Introduction}

Calcium carbonate $\left(\mathrm{CaCO}_{3}\right)$ is one of the most abundant minerals in nature and widely used as filling material in various industries in order to decrease the product costs and to improve some of the mechanical properties of the composite materials. The enhancement in the physical and mechanical properties of the polymeric composite materials is more pronounced when the particles are in nano-sizes (Lin et al., 2008). Nano-calcite can be produced by recrystallization methods utilizing calcium hydroxide $\left(\mathrm{Ca}(\mathrm{OH})_{2}\right)$ and carbon dioxide $\left(\mathrm{CO}_{2}\right)$ as in the carbonization method, and calcium chloride $\left(\mathrm{CaCl}_{2}\right)$ and sodium carbonate $\left(\mathrm{NaCO}_{3}\right)$ as in the chemical method (Carmona et al., 2003a, 2004; Chen et al., 2000; Ukrainczyk et al., 2007). However, obtaining $\mathrm{CaCO}_{3}$ particles in nano-sizes with homogeneous size distribution, and different morphologies is difficult due to agglomeration of newly synthesized clusters (Gebauer et al., 2008; Kellermeier et al., 2012; Kilic and Ozdemir, 2015; Pouget et al., 2009), which is related to the surface potential of the colloidal $\mathrm{CaCO}_{3}$ particles (Agnihotri et al., 1999; Holysz et al., 2003; Moulin and Roques, 2003; Pourchet et al., 2013). $\mathrm{CaCO}_{3}$ is also one of the principal constituents of hard scale formed in many industrial and heating installations. One of the causes for scale formation is the surface charge which is one of the most important parameters in dissolution and precipitation of $\mathrm{CaCO}_{3}$ (Chibowski et al., 2003a, 2003b; Yuan et al., 2008).

Calcium carbonate has three different anhydrous polymorphs known as calcite, aragonite, and vaterite. Calcite is the most stable form of the $\mathrm{CaCO}_{3}$ at standard conditions. Aragonite and vaterite are

\footnotetext{
* Corresponding author.

E-mail address: ekremozdemir@iyte.edu.tr (E. Ozdemir).
}

not stable, but they can transform into the stable calcite (Stepkowska et al., 2003). $\mathrm{CaCO}_{3}$ has also other hydrous forms such as calcium carbonate monohydrate, calcium carbonate hexahydrate, and amorphous calcium carbonate (ACC)(García-Carmona et al., 2003; Gunasekaran and Anbalagan, 2008; Jung et al., 2000; Montes-Hernandez et al., 2008; Xu et al., 2007).

Classical crystallization mechanisms claim that a nucleation step is required before crystal growth (Xu et al., 2007). However, novel crystallization mechanisms require a prenucleation process in which ions form stable clusters (Gebauer et al., 2008). These clusters are charged particles in equilibrium with their ions and they can grow or collide to produce amorphous $\mathrm{CaCO}_{3}$ nuclei (Bots et al., 2012). Therefore, certain additives were introduced into the crystal growing medium to alter the surface charge of the growing nuclei and to inhibit the $\mathrm{CaCO}_{3}$ growth (Liu et al., 2008; Seo et al., 2005; Sheng et al., 2004).

The surface potential of the colloidal system is related to the magnitude of the zeta potential. Zeta potential is also the most effective parameter to calculate interaction energy between particles for the colloidal stability. Particles with zeta potentials more positive than $+30 \mathrm{mV}$ or more negative than $-30 \mathrm{mV}$ are considered stable (Kes, 2007). However, a neat consensus could not be arrived by the authors on the zeta potential for the $\mathrm{CaCO}_{3}$ in the literature because sometimes positive, sometimes negative, and sometimes variable zeta potential values have been reported (Moulin and Roques, 2003). The zeta potential for $\mathrm{CaCO}_{3}$ was reported to be about $-10 \mathrm{mV}$ (Chibowski et al., $2003 \mathrm{~b}$ ) indicating that the newly produced $\mathrm{CaCO}_{3}$ clusters are naturally unstable. It is the reason why newly formed particles in the literature with the chemical or carbonization methods were aggregated and formed micron sized particles (Carmona et al., 2003a, 2003b; Kilic and Ozdemir, 2015; Kitamura et al., 2002; Rodriguez-Blanco et al., 2011; 
Tai and Chen, 1998; Yan et al., 2008). It was understood that the surface potential for $\mathrm{CaCO}_{3}$ is affected by various parameters such as aging (Chibowski et al., 2003b), additives (Yuan et al., 2008), surface modifiers (Agnihotri et al., 1999), and ions (Holysz et al., 2003; Pourchet et al., 2013). For instance, the zeta potential for $\mathrm{CaCO}_{3}$ was positive when $\mathrm{Ca}^{++}$ions were in excess in the solution, and it was negative when $\mathrm{CO}_{3}=$ ions were in excess in the solution (Chibowski et al., 2003b; Holysz et al., 2003; Pourchet et al., 2013). Therefore, the presence of other ions, called the potential determining ions (PDI) (Moulin and Roques, 2003) such as crystal lattice ions, surface hydrolysis ions, and adsorbing ions in solution, are highly important for the aggregation and growth of $\mathrm{CaCO}_{3}$ on the surfaces as well as production of stable nano- $\mathrm{CaCO}_{3}$ particles.

In our previous paper, we have reported the production and aggregation of nano-clusters in $\mathrm{CaCO}_{3}$ crystallization (Kilic and Ozdemir, 2015). We have shown that monodispersed nano- $\mathrm{CaCO}_{3}$ particles could be produced if the stability of the clusters could be achieved in the colloidal solution. Here, the stability of $\mathrm{CaCO}_{3}$ particles in $\mathrm{Ca}(\mathrm{OH})_{2}$ solution was investigated in an effort to stabilize the newly produced $\mathrm{CaCO}_{3}$ clusters before their aggregation into the growing crystals.

\section{Materials and methods}

\subsection{Materials}

Calcium hydroxide was purchased from Merck with a purity of $96 \%$ of which $3 \%$ was $\mathrm{CaCO}_{3}$, and $1 \%$ was other impurities (mainly $0.05 \%$ of $\mathrm{Na}, \mathrm{K}$, $\mathrm{Fe}, \mathrm{Sr} ; 0.5 \%$ of $\mathrm{Mg} ; 0.01 \%$ of $\mathrm{SO}_{4}^{\bar{y}}$, and $0.005 \%$ of $\mathrm{Cl}^{-}$). Calcium carbonate was also purchased from Merck with a purity of 98.5\%-100.5\%. Ultrapure water was obtained with a MilliQ (Millipore-Elix UV5/Milli-Q) water purification system with a purity of $18.2 \mu \Omega$ at $25^{\circ} \mathrm{C}$.

\subsection{Dissolution of $\mathrm{Ca}(\mathrm{OH})_{2}$ in ultrapure water}

The dissolution of $\mathrm{Ca}(\mathrm{OH})_{2}$ was performed in a 5-neck jacketed reactor at $23^{\circ} \mathrm{C}$ as shown in Fig. 1. Before the experiments, nitrogen gas $\left(\mathrm{N}_{2}\right)$ was fed into the reactor to maintain a $\mathrm{CO}_{2}$-free atmosphere in the reactor. Conductivity and $\mathrm{pH}$ values were measured by Thermo Orion 5 star $\mathrm{pH}$ meter with $\mathrm{pH}$ and conductivity probes. The measured data were monitored and recorded with a Thermo Star Navigator 21 software program. Initially, $250 \mathrm{~mL}$ of ultrapure water was filled into the five neck reactor and stirred at $550 \mathrm{rpm}$ on a magnetic stir plate. Both $\mathrm{pH}$ and conductivity were monitored for about $15 \mathrm{~min}$. Then, $0.0185 \mathrm{~g}$ of $\mathrm{Ca}(\mathrm{OH})_{2}$ were added in the ultrapure water in order to prepare a $1 \mathrm{mM}$ of $\mathrm{Ca}(\mathrm{OH})_{2}$ solution. Both $\mathrm{pH}$ and conductivity were monitored during the dissolution process for about $30 \mathrm{~min}$. After $15 \mathrm{~min}$ of stirring, about $1 \mathrm{ml}$ of sample was withdrawn from the solution into a UV cuvette and size and size distribution were measured using a particle

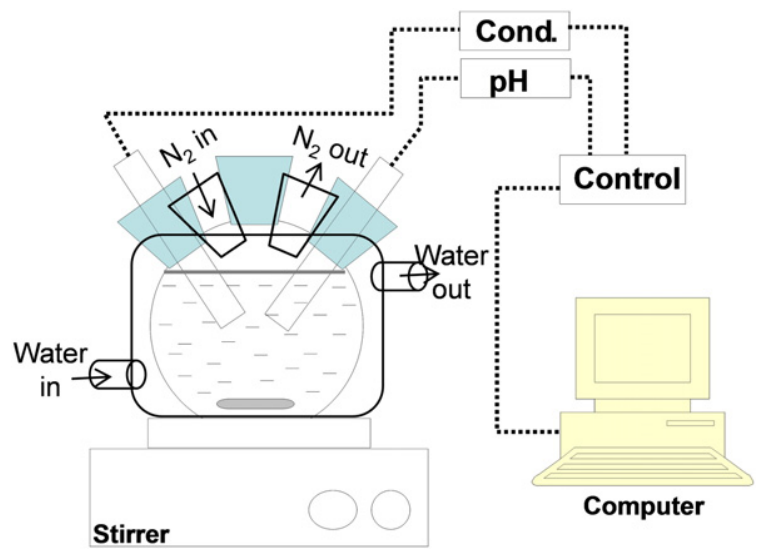

Fig. 1. A five neck glass reactor for the stability study of $\mathrm{CaCO}_{3}$ in $\mathrm{Ca}(\mathrm{OH})_{2}$ solution.

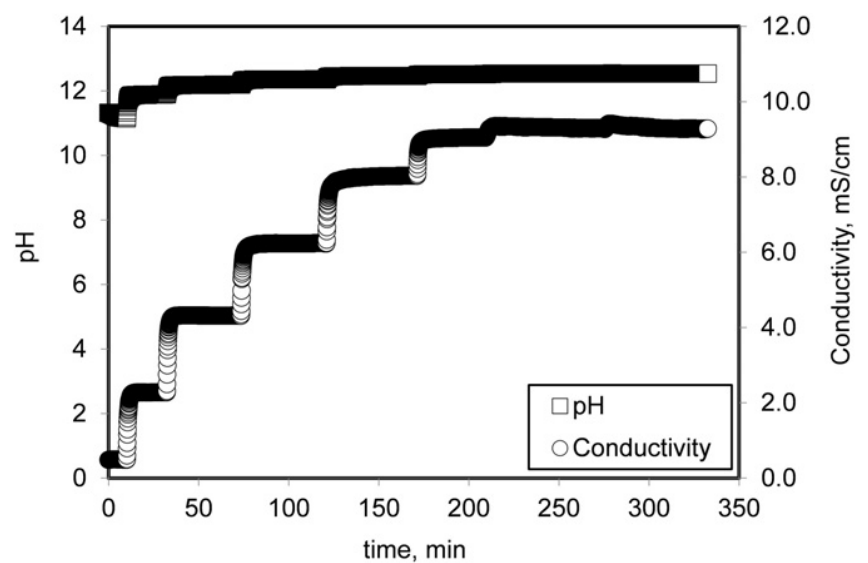

Fig. 2. Change of $\mathrm{pH}$ and conductivity in the presence of various $\mathrm{Ca}(\mathrm{OH})_{2}$ additions.

size analyzer (Malvern nano ZS model). A $1 \mathrm{ml}$ of sample was also withdrawn from the solution into a zeta cell and zeta potential values were measured. Solutions were returned to the reactor after each measurement. Reported size and zeta potential values are the average of at least five measurements conducted on the same sample and reported their average values. In order to increase the $\mathrm{Ca}(\mathrm{OH})_{2}$ concentration, $0.037 \mathrm{~g}, 0.0375 \mathrm{~g}, 0.092 \mathrm{~g}, 0.092 \mathrm{~g}, 0.093 \mathrm{~g}, 0.185 \mathrm{~g}, 0.371 \mathrm{~g}$, and $0.926 \mathrm{~g}$ of $\mathrm{Ca}(\mathrm{OH})_{2}$ powders were added sequentially into the solution to obtain $3 \mathrm{mM}, 5 \mathrm{mM}, 10 \mathrm{mM}, 15 \mathrm{mM}, 20 \mathrm{mM}, 30 \mathrm{mM}, 50 \mathrm{mM}$, and $100 \mathrm{mM}$ of $\mathrm{Ca}(\mathrm{OH})_{2}$ solutions, respectively. At the end of each addition, both particle size distribution and zeta potential measurements were conducted.

\subsection{Dissolution of $\mathrm{CaCO}_{3}$ in ultrapure water}

The dissolution of $\mathrm{CaCO}_{3}$ was also performed in the same set-up as shown in Fig. 1. $250 \mathrm{ml}$ of ultrapure water was placed in the five neck reactor and stirred at $550 \mathrm{rpm}$ on a magnetic stir plate. Both $\mathrm{pH}$ and conductivity values were monitored online using the Thermo Orion $\mathrm{pH}$-meter software. Then, $0.025 \mathrm{~g}$ of $\mathrm{CaCO}_{3}$ powder was added to the ultrapure water to obtain $1 \mathrm{mM}$ of $\mathrm{CaCO}_{3}$ solution. After about $15 \mathrm{~min}$ of stirring, $1 \mathrm{ml}$ of sample was withdrawn to measure the particle size distribution and another $1 \mathrm{ml}$ of sample was withdrawn from the reactor to conduct the zeta potential measurements. The solutions were returned into the reactor after each measurement. In order to increase the $\mathrm{CaCO}_{3}$ concentration in the reactor, $0.05 \mathrm{~g}, 0.05 \mathrm{~g}, 0.125 \mathrm{~g}, 0.125 \mathrm{~g}$, $0.125 \mathrm{~g}, 0.250 \mathrm{~g}, 0.501 \mathrm{~g}$, and $1.151 \mathrm{~g}$ of $\mathrm{CaCO}_{3}$ powder was added

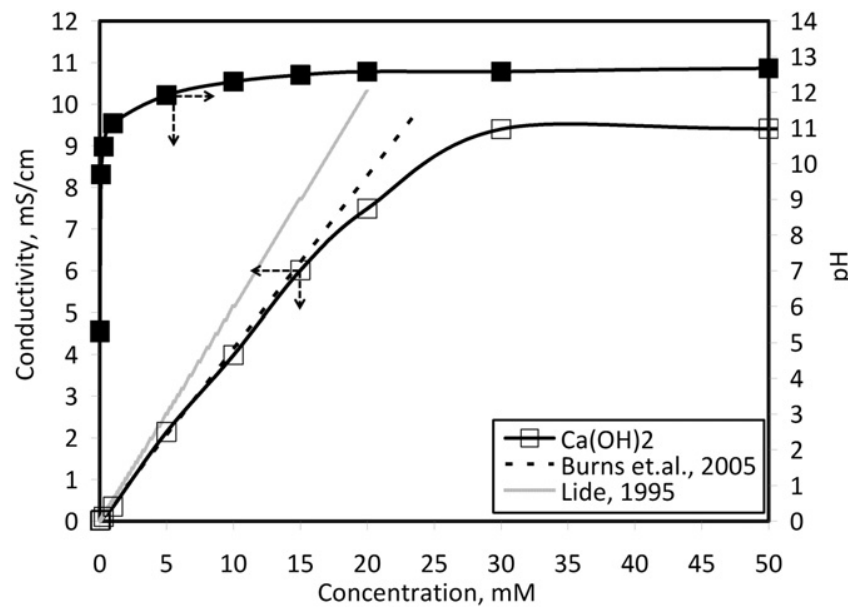

Fig. 3. Conductivity and $\mathrm{pH}$ values with $\mathrm{Ca}(\mathrm{OH})_{2}$ concentration and a comparison with the literature data. 


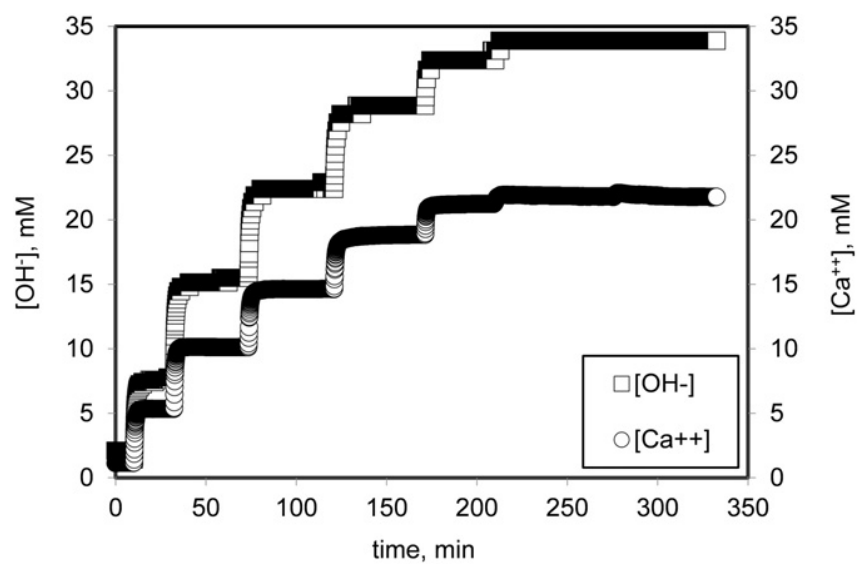

Fig. 4. Calculated $\mathrm{OH}^{-}$and $\mathrm{Ca}^{++}$ion concentrations in $\mathrm{Ca}(\mathrm{OH})_{2}$ solution.

sequentially into the solution to prepare a $3 \mathrm{mM}, 5 \mathrm{mM}, 10 \mathrm{mM}, 15 \mathrm{mM}$, $20 \mathrm{mM}, 30 \mathrm{mM}, 50 \mathrm{mM}$, and $100 \mathrm{mM} \mathrm{CaCO}_{3}$ solutions, respectively.

\subsection{Dissolution of $\mathrm{Ca}(\mathrm{OH})_{2}$ in $10 \mathrm{mM}$ of $\mathrm{CaCO}_{3}$ slurry}

The dissolution of $\mathrm{Ca}(\mathrm{OH})_{2}$ in $10 \mathrm{mM}$ of $\mathrm{CaCO}_{3}$ solution were performed with the same procedure. Initially, $10 \mathrm{mM}$ of $\mathrm{CaCO}_{3}$ solution was prepared by adding $0.25 \mathrm{~g}$ of $\mathrm{CaCO}_{3}$ powder into $250 \mathrm{ml}$ of ultrapure water by stirring at $550 \mathrm{rpm}$ on a magnetic stir plate. Both $\mathrm{pH}$ and conductivity values were monitored during the dissolution. After equilibration, both particle size distribution and zeta potential values were measured with the Malvern zeta sizer by withdrawing $1 \mathrm{ml}$ samples for each as explained above. Then, $0.0185 \mathrm{~g}$ of $\mathrm{Ca}(\mathrm{OH})_{2}$ powder was added into the solution to obtain $1 \mathrm{mM}$ of $\mathrm{Ca}(\mathrm{OH})_{2}$ solution in $250 \mathrm{ml}$ of $10 \mathrm{mM} \mathrm{CaCO}_{3}$ slurry. Both $\mathrm{pH}$ and conductivity values were monitored. After about $15 \mathrm{~min}$, both particle size distribution and zeta potential values were measured by withdrawing $1 \mathrm{ml}$ of samples for each measurement. Sequential addition of $\mathrm{Ca}(\mathrm{OH})_{2}$ powders was done into the slurry in order to prepare $5 \mathrm{mM}, 10 \mathrm{mM}$, and up to $100 \mathrm{mM}$ of $\mathrm{Ca}(\mathrm{OH})_{2}$ solutions, respectively, in $10 \mathrm{mM}$ of $\mathrm{CaCO}_{3}$ slurry.

\subsection{Dissolution of $\mathrm{CaCO}_{3}$ in $10 \mathrm{mM}$ of $\mathrm{Ca}(\mathrm{OH})_{2}$ solution}

The dissolution of $\mathrm{CaCO}_{3}$ in $10 \mathrm{mM}$ of $\mathrm{Ca}(\mathrm{OH})_{2}$ were also conducted with the same procedure explained above. Initially, $10 \mathrm{mM}$ of $\mathrm{Ca}(\mathrm{OH})_{2}$ solution was prepared by adding $0.185 \mathrm{~g}$ of $\mathrm{Ca}(\mathrm{OH})_{2}$ powder into a $250 \mathrm{ml}$ of ultrapure water by stirring at $550 \mathrm{rpm}$ on a magnetic stir plate. Both $\mathrm{pH}$ and conductivity values were monitored as briefly described before. After equilibration, both particle size distribution and zeta potential values were measured with the Malvern zeta sizer by withdrawing $1 \mathrm{ml}$ sample for each. Then, $0.018 \mathrm{~g}$ of $\mathrm{CaCO}_{3}$ powder was added into the solution to obtain $1 \mathrm{mM}$ of $\mathrm{CaCO}_{3}$ solution in
$10 \mathrm{mM}$ of $\mathrm{Ca}(\mathrm{OH})_{2}$ solution. Both $\mathrm{pH}$ and conductivity measurements were conducted and monitored during dissolution. After about $20 \mathrm{~min}$, both particle size distribution and zeta potential values were measured by withdrawing $1 \mathrm{ml}$ of sample for each. $0.0815 \mathrm{~g}$ of $\mathrm{CaCO}_{3}$ powder was added into the solution in order to prepare $4 \mathrm{mM}$ slurry, and subsequently additional $\mathrm{CaCO}_{3}$ powders were added to prepare $10 \mathrm{mM}, 15 \mathrm{mM}$, and up to $100 \mathrm{mM}$ of $\mathrm{CaCO}_{3}$ slurries, respectively, in $10 \mathrm{mM}$ of $\mathrm{Ca}(\mathrm{OH})_{2}$ solution.

\subsection{Scanning electron microscope (SEM) images of the samples}

A small amount of sample was removed from the solution and transferred in a $2 \mathrm{ml}$ Eppendorf tube and centrifuged for $10 \mathrm{~min}$ at $9000 \mathrm{rpm}$ (Universal 320 - Hettich Zentrifugen). All samples were dried in an oven at $103{ }^{\circ} \mathrm{C}$ (Nüve FN 500) overnight before SEM imaging. The morphologies of the crystals were analyzed using a scanning electron microscope (SEM) fitted with a field emission source (Philips XL 30 S FEG), operating at an accelerating voltage of $15 \mathrm{kV}$. The crystals were mounted on copper sample stubs with conducting carbon tape for SEM viewing.

\section{Results and discussion}

\subsection{Dissolution of commercial $\mathrm{Ca}(\mathrm{OH})_{2}$ in ultrapure water}

Commercial $\mathrm{Ca}(\mathrm{OH})_{2}$ was dissolved in the ultrapure water in a stepwise fashion at concentrations up to $100 \mathrm{mM}$. Fig. 2 shows the $\mathrm{pH}$ and conductivity values by time after each addition of $\mathrm{Ca}(\mathrm{OH})_{2}$ powders into ultrapure water. The initial concentration for $\mathrm{Ca}(\mathrm{OH})_{2}$ was $1 \mathrm{mM}$ and it was expected that the whole powder added into the solution dissolved completely according to chemical speciation to an equilibrium as summarized in Eqs. (1) through (3) (Chibowski et al., 2003b).

$$
\begin{array}{ll}
\mathrm{Ca}(\mathrm{OH})_{2}(\mathrm{~s}) \rightleftharpoons \mathrm{Ca}(\mathrm{OH})_{2}(\mathrm{aq}) & \mathrm{pK}_{\mathrm{a}}=-2.45 \\
\mathrm{Ca}(\mathrm{OH})_{2}(\mathrm{aq}) \rightleftharpoons \mathrm{Ca}(\mathrm{OH})^{+}+\mathrm{OH}^{-} & \mathrm{pK}_{\mathrm{a}}=-1.37 \\
\mathrm{Ca}(\mathrm{OH})^{+} \rightleftharpoons \mathrm{Ca}^{++}+\mathrm{OH}^{-} & \mathrm{pK}_{\mathrm{a}}=-1.40
\end{array}
$$

Wang (Wang et al., 1998) studied the dissolution mechanism of $\mathrm{Ca}(\mathrm{OH})_{2}$ by the rotating disk method and reported that while the $\mathrm{Ca}^{++}$ions dissolved into the solution, $\mathrm{OH}^{-}$ions remained on the surface as shown in Eq. (4). Later on, the $\mathrm{OH}^{-}$ions released from the surface were attacked by the free $\mathrm{Ca}^{++}$ions in the solution as shown in Eq. (5). The dissolution of powder $\mathrm{Ca}(\mathrm{OH})_{2}$ was also studied by Johannsen and Rademacher (Johannsen and Rademacher, 1999). The authors suggested that the particle size and therefore the surface area were the main factors in $\mathrm{Ca}(\mathrm{OH})_{2}$ dissolution kinetics.

$\mathrm{Ca}(\mathrm{OH})_{2} \longrightarrow \mathrm{Ca}^{++}+2 \mathrm{OH}^{-}($surface $)$
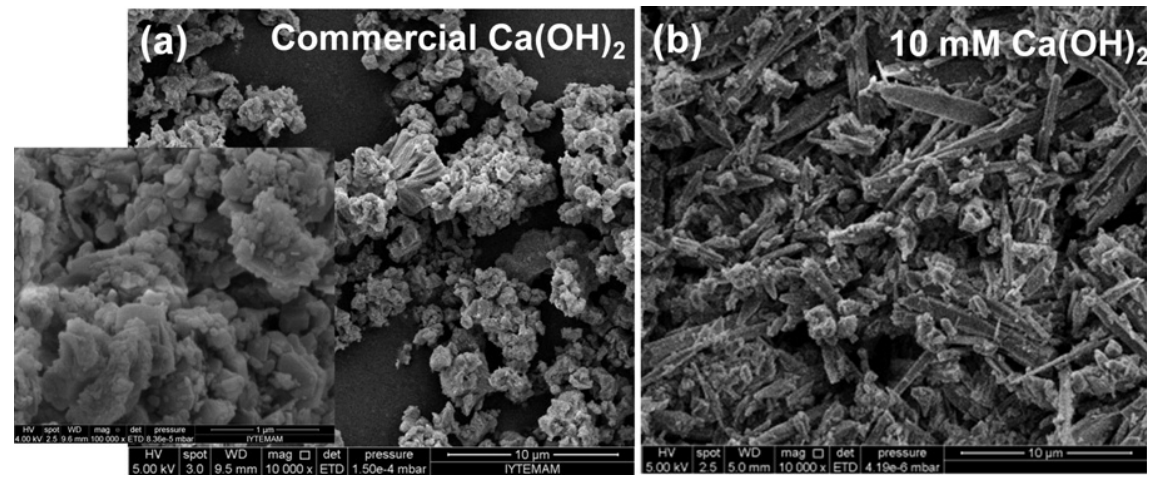

Fig. 5. SEM images of (a) as-received commercial $\mathrm{Ca}(\mathrm{OH})_{2}$ and (b) debris in $10 \mathrm{mM}$ of dissolved $\mathrm{Ca}(\mathrm{OH})_{2}$. 
$\mathrm{Ca}^{++}+2 \mathrm{OH}^{-}($surface $) \longrightarrow \mathrm{Ca}^{++}+2 \mathrm{OH}^{-}$(bulk solution $)$

Sequentially added $\mathrm{Ca}(\mathrm{OH})_{2}$ powders were allowed to dissolve in a solution composed of previously produced $\mathrm{Ca}^{++}, \mathrm{OH}^{-}$, and $\mathrm{Ca}(\mathrm{OH})^{+}$ ions, as well as the clusters and solid particles in the solution. As can be seen in Fig. 2, the conductivity and $\mathrm{pH}$ values increased proportionally by the subsequent additions of $\mathrm{Ca}(\mathrm{OH})_{2}$ powders, however, no significant changes were observed above the saturation concentration of $\mathrm{Ca}(\mathrm{OH})_{2}$, which is about $18 \mathrm{mM}$ at $23{ }^{\circ} \mathrm{C}$ (Lide, 1995).

Conductivity and $\mathrm{pH}$ values obtained after each $\mathrm{Ca}(\mathrm{OH})_{2}$ addition are shown in Fig. 3. Literature data are also included in the figure for comparison. As shown in the figure, the conductivity values increased linearly with $\mathrm{Ca}(\mathrm{OH})_{2}$ concentration up to the solubility limit of about $18 \mathrm{mM}$. Then, a plateau was reached where both the conductivity and $\mathrm{pH}$ values remained unchanged at concentrations higher than $30 \mathrm{mM}$ due to formation of slurry. The linear relationship between $\mathrm{Ca}(\mathrm{OH})_{2}$ concentration and the conductivity value agrees very well with the data reported by Burns et al. (Burns and Jachuck, 2005). Both data are below the theoretical dissolution limit of $\mathrm{Ca}(\mathrm{OH})_{2}$ reported by Lide (Lide, 1995) due to the complex formation between the $\mathrm{Ca}^{++}$and $\mathrm{OH}^{-}$ions and possible surface attachments of ions on the undissolved impurities such as impurity $\mathrm{CaCO}_{3}$ particles. Burns and Jachuck (Burns and Jachuck, 2005) stated that the conductivity values deviated about $24 \%$ from the theoretical values. This difference may explain the complex formation between $\mathrm{Ca}^{++}, \mathrm{OH}^{-}$, and $\mathrm{CO}_{3}{ }^{-}$ions in the solution below the solubility limit. Above the solubility limit, beside complex formation between ions, considerable amount of $\mathrm{Ca}(\mathrm{OH})_{2}$ probably remained undissolved in ultrapure water.

As shown in Fig. 3, the linear increase in conductivity values could be related to the $\mathrm{Ca}(\mathrm{OH})_{2}$ concentration up to the saturation limit since beyond that point, the conductivity values did not change with further addition of $\mathrm{Ca}(\mathrm{OH})_{2}$. From the slope in Fig. 3,

Conductivity $=0.4268\left[\mathrm{Ca}(\mathrm{OH})_{2}\right]$

where conductivity is in $\mathrm{mS} / \mathrm{cm}$ and $\left[\mathrm{Ca}(\mathrm{OH})_{2}\right]$ is in $\mathrm{mM}$. The $\left[\mathrm{Ca}^{++}\right]$ ion concentration could be related to the linearity of $\left[\mathrm{Ca}(\mathrm{OH})_{2}\right]$ concentration up to the solubility limit of $\mathrm{Ca}(\mathrm{OH})_{2}$ provided that $1 \mathrm{~mol}$ of $\left[\mathrm{Ca}^{++}\right]$ion were produced from $1 \mathrm{~mol}$ of $\mathrm{Ca}(\mathrm{OH})_{2}$ dissolved. Therefore, the $\left[\mathrm{Ca}^{++}\right]$ion concentration in the $\mathrm{Ca}(\mathrm{OH})_{2}$ solution can be estimated from the measured conductivity values by using Eq. (7).

$\left[\mathrm{Ca}^{++}\right]=$Conductivity $\times \frac{1}{\text { slope }}$

The $\left[\mathrm{OH}^{-}\right]$ion concentration can be calculated from the measured $\mathrm{pH}$ values as given in Eq. (8).

$\left[\mathrm{OH}^{-}\right]=10^{(-(14-\mathrm{pH}))}$

The $\left[\mathrm{Ca}^{++}\right]$and $\left[\mathrm{OH}^{-}\right]$ion concentrations during the addition of $\mathrm{Ca}(\mathrm{OH})_{2}$ were calculated respectively from Eqs. (7) and (8), and shown in Fig. 4. Theoretically, $15 \mathrm{mM}\left[\mathrm{Ca}^{++}\right]$and $30 \mathrm{mM}\left[\mathrm{OH}^{-}\right]$ion concentrations would be obtained when a stoichiometric $15 \mathrm{mM}$ of $\mathrm{Ca}(\mathrm{OH})_{2}$ was dissolved in ultrapure water. Moreover, $\left[\mathrm{OH}^{-}\right]$ion concentration would theoretically be two times bigger than the $\left[\mathrm{Ca}^{++}\right]$ ion concentration. However, as shown in the figure, while the $\left[\mathrm{Ca}^{++}\right]$ ion concentration was estimated to be about $15 \mathrm{mM}$, the $\left[\mathrm{OH}^{-}\right]$ion concentration was calculated to be about $22 \mathrm{mM}$, which was smaller than the theoretical value (Lide, 1995) as described also by Burns and Jachuck (Burns and Jachuck, 2005). The $\left[\mathrm{OH}^{-}\right]$ion concentration was not 2 times higher than $\left[\mathrm{Ca}^{++}\right]$ion concentration, indicating that surface adsorption of ions on the solid particles, new particle formation, and clustering of ions can take place in the solution. As understood from these $\left[\mathrm{Ca}^{++}\right]$and $\left[\mathrm{OH}^{-}\right]$ion concentration data, surface charge

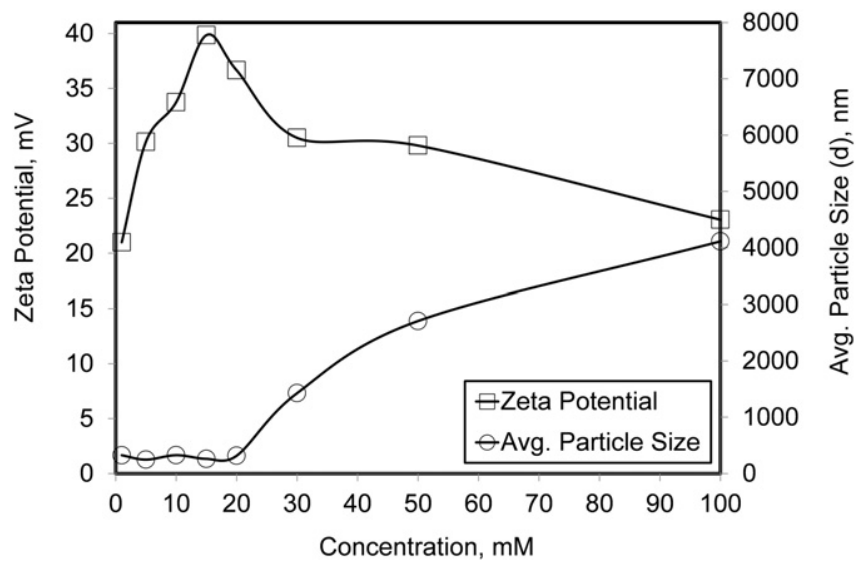

Fig. 6. Zeta potential and average particle size values obtained by different $\mathrm{Ca}(\mathrm{OH})_{2}$ dissolution.

and clustering may affect the size distribution and the zeta potential values of particles in aggregation and growth of $\mathrm{CaCO}_{3}$ as well as nano- $\mathrm{CaCO}_{3}$ production.

Fig. 5 shows SEM images of as-received commercial $\mathrm{Ca}(\mathrm{OH})_{2}$ powder and any residues remained in $10 \mathrm{mM}$ of dissolved $\mathrm{Ca}(\mathrm{OH})_{2}$. As shown in the figure, the commercial $\mathrm{Ca}(\mathrm{OH})_{2}$ is composed of fine particles aggregated into big flocks. As mentioned before, the $\mathrm{Ca}(\mathrm{OH})_{2}$ used in the experiments had an impurity of $3 \%$ of $\mathrm{CaCO}_{3}$ and $1 \%$ of the other impurities. The composition of the powders and the resulting dissolution products were not analyzed as a matter of fact they were both commercial $\mathrm{Ca}(\mathrm{OH})_{2}$ and $\mathrm{CaCO}_{3}$. As shown in Fig. 5b, the impurities obtained after centrifugation of $10 \mathrm{mM}$ of $\mathrm{Ca}(\mathrm{OH})_{2}$ solution were needle-like aragonite type $\mathrm{CaCO}_{3}$ crystals. Newly formed nano- $\mathrm{CaCO}_{3}$ crystals and aggregated nano-particles were also discerned in the image. We believe that these nano-particles were formed due to dissolution and reprecipitation of $\mathrm{CaCO}_{3}$ particles in the solution.

The measured zeta potential and average particle sizes in $\mathrm{Ca}(\mathrm{OH})_{2}$ solution are shown in Fig. 6 . As can be seen in the figure, the measured zeta potential value and the average particle size were about $20 \mathrm{mV}$ and about $300 \mathrm{~nm}$, respectively, for the initially prepared $1 \mathrm{mM}$ of $\mathrm{Ca}(\mathrm{OH})_{2}$ solution. As seen from the SEM images in Fig. 5b, the impurity in the $\mathrm{Ca}(\mathrm{OH})_{2}$ solution was needle-like aragonite type $\mathrm{CaCO}_{3}$ and the average particle size was bigger than the measured value of $300 \mathrm{~nm}$. Therefore, the reported nano-particles were most probably the newly synthesized nano- $\mathrm{CaCO}_{3}$ particles with a zeta potential value of about $20 \mathrm{mV}$. Upon subsequent addition of $\mathrm{Ca}(\mathrm{OH})_{2}$ into the previously $\mathrm{Ca}(\mathrm{OH})_{2}$ dissolved solution, the zeta potential value for the $\mathrm{Ca}(\mathrm{OH})_{2}$ was seen to increase gradually to about $40 \mathrm{mV}$ while the average particle size remained the same up to the solubility value of about $18 \mathrm{mM}$. Chibowski et al.

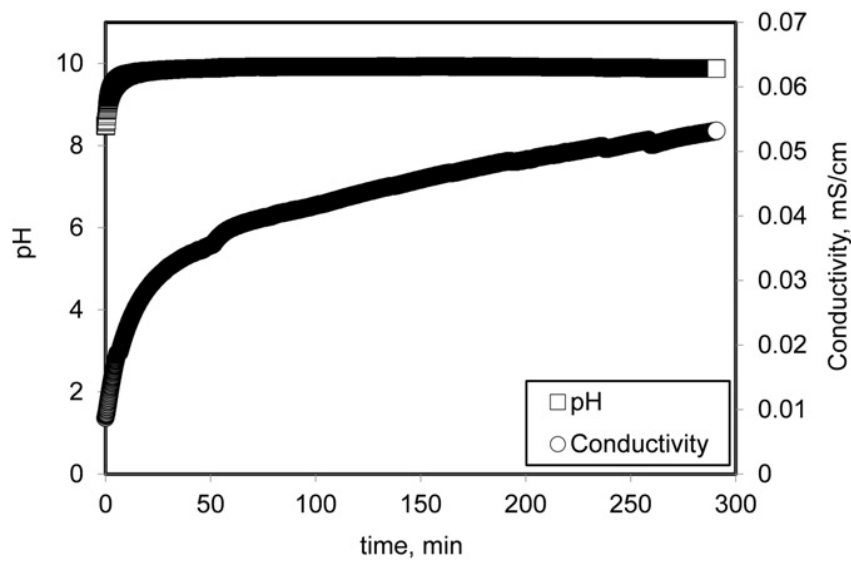

Fig. 7. $\mathrm{pH}$ and conductivity values obtained by various $\mathrm{CaCO}_{3}$ addition. 


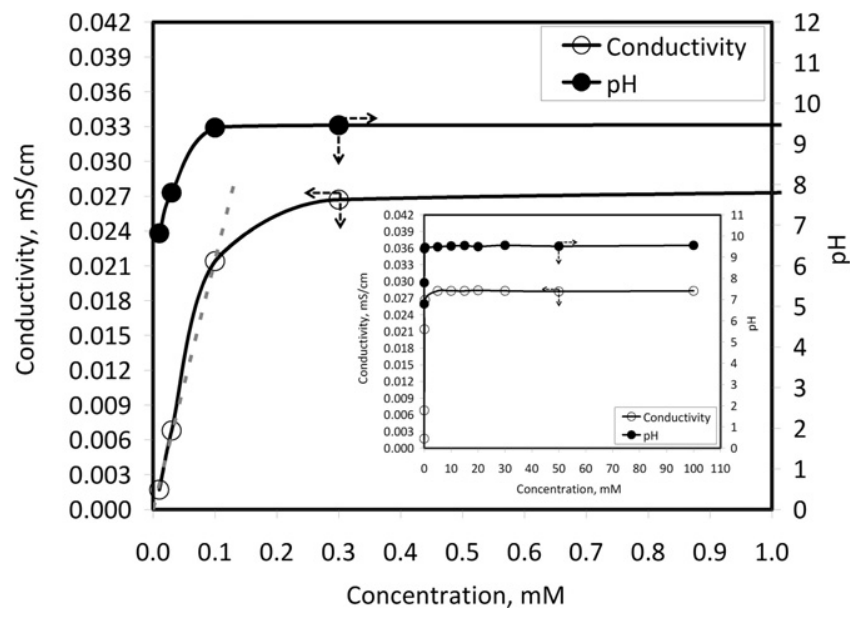

Fig. 8. Variation of conductivity and $\mathrm{pH}$ values with changing $\mathrm{CaCO}_{3}$ concentration.

(2003a, 2003b, 2003c) stated that the positive net charge on the $\mathrm{CaCO}_{3}$ surface depends on the surface $\mathrm{Ca}^{++}$sites (Chibowski et al., 2003c). The authors also stated that zeta potential of precipitated $\mathrm{CaCO}_{3}$ from equimolar concentration of $\mathrm{Ca}^{++}$and $\mathrm{CO}_{3}=$ was around zero or, slightly higher than zero. It was understood that the zeta potential of $\mathrm{CaCO}_{3}$ precipitated from excess of $\mathrm{CO}_{3}{ }^{\overline{ }}$ was negative, and the zeta potential of $\mathrm{CaCO}_{3}$ precipitated from excess of $\mathrm{Ca}^{++}$was positive. It was presumed that the $\mathrm{Ca}^{++}$ion concentration seemed to be higher in the fully dissolved $\mathrm{Ca}(\mathrm{OH})_{2}$ solution than the $\mathrm{CO}_{3}=$ ion concentration resulting in a net positive zeta potential value. Upon further addition of the $\mathrm{Ca}(\mathrm{OH})_{2}$ powder into the solution, the average particle size showed an increase up to $4 \mu \mathrm{m}$ due to the insoluble $\mathrm{Ca}(\mathrm{OH})_{2}$ powder, and the zeta potential values decreased from $40 \mathrm{mV}$ to $30 \mathrm{mV}$ and then to $23 \mathrm{mV}$ at the highest concentration of $100 \mathrm{mM}$. The measured positive zeta potential values higher than $+30 \mathrm{mV}$ indicate that the newly produced nano- $\mathrm{CaCO}_{3}$ particles were abundant and in stable form in the solution, exhibiting no aggregation after they formed.

\subsection{Dissolution of $\mathrm{CaCO}_{3}$ in ultrapure water}

Fig. 7 shows the change in $\mathrm{pH}$ and conductivity values with time during sequential addition of commercial $\mathrm{CaCO}_{3}$ into ultrapure water. The solubility of $\mathrm{CaCO}_{3}$ was reported to be about $0.013 \mathrm{~g} / \mathrm{kg}$-water in the literature (Perry et al., 1984), which is very low compared to that for the $\mathrm{Ca}(\mathrm{OH})_{2}$. As can be seen in the figure, both $\mathrm{pH}$ and conductivity values slightly increased at low concentrations up to about $0.13 \mathrm{mM}$ of $\mathrm{CaCO}_{3}$ solutions. Although the increase in the conductivity was slight, it was not relatively stable due to the formation of additional ions and

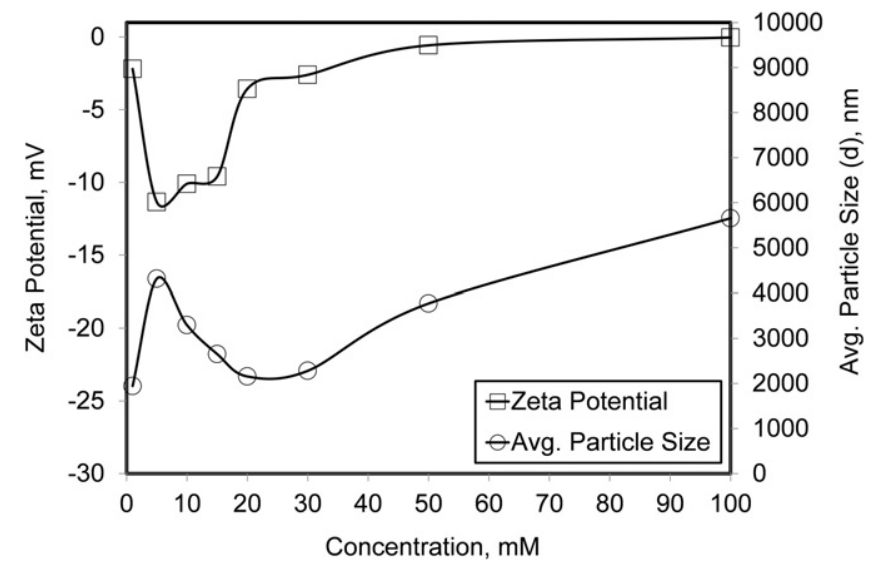

Fig. 10. Change of zeta potential and average particle size in the presence of various $\mathrm{CaCO}_{3}$ addition.

clusters (Chibowski et al., 2003b). Dissolution of small amount of $\mathrm{CaCO}_{3}$ at concentrations less than $0.13 \mathrm{mM}$ resulted in $\mathrm{Ca}^{++}$and $\mathrm{CO}_{3}=$ ions to present in the solution according to Eqs. (9) and (10) (Chibowski et al., 2003b; Holysz et al., 2003; Moulin and Roques, 2003).

$$
\begin{array}{ll}
\mathrm{CaCO}_{3}(\mathrm{~s}) \rightleftharpoons \mathrm{CaCO}_{3}(\mathrm{aq}) & \mathrm{pK}_{\mathrm{a}}=-5.09 \\
\mathrm{CACO}_{3}(\mathrm{aq}) \rightleftharpoons \mathrm{Ca}^{++}+\mathrm{CO}_{3}= & \mathrm{pK}_{\mathrm{a}}=-3.25
\end{array}
$$

However, the free $\mathrm{CO}_{3}=$ ions in the solution caused a carbonate buffer to form, forming a $\mathrm{CO}_{2}$ gas and additional $\mathrm{HCO}_{3}^{-}$and $\mathrm{OH}^{-}$ions. The steady increase in the conductivity was probably due to the formation of other ions in the solution. In the presence of $\mathrm{CO}_{2}$ gas or when the $\mathrm{CaCO}_{3}$ solution is open to the atmosphere, the carbonate buffer also affected the $\mathrm{CaCO}_{3}$ dissolution dynamics as well as the surface potential according to Eqs. (11) to (13) (Chibowski et al., 2003b; Holysz et al., 2003; Moulin and Roques, 2003).

$$
\begin{array}{ll}
\mathrm{CO}_{3}{ }^{-}+\mathrm{H}_{2} \mathrm{O} \rightleftharpoons \mathrm{HCO}_{3}{ }^{-}+\mathrm{OH}^{-} & \mathrm{pK}_{\mathrm{a}}=-3.67 \\
\mathrm{HCO}_{3}{ }^{-}+\mathrm{H}_{2} \mathrm{O} \rightleftharpoons \mathrm{H}_{2} \mathrm{CO}_{3}+\mathrm{OH}^{-} & \mathrm{pK}_{\mathrm{a}}=-7.65 \\
\mathrm{H}_{2} \mathrm{CO}_{3} \rightleftharpoons \mathrm{CO}_{2}(\mathrm{~g})+\mathrm{H}_{2} \mathrm{O} & \mathrm{pK}_{\mathrm{a}}=+1.47
\end{array}
$$

In the presence of carbonate buffer, additional ions, clusters, and nano-particles could form due to dissolution and recrystallization of
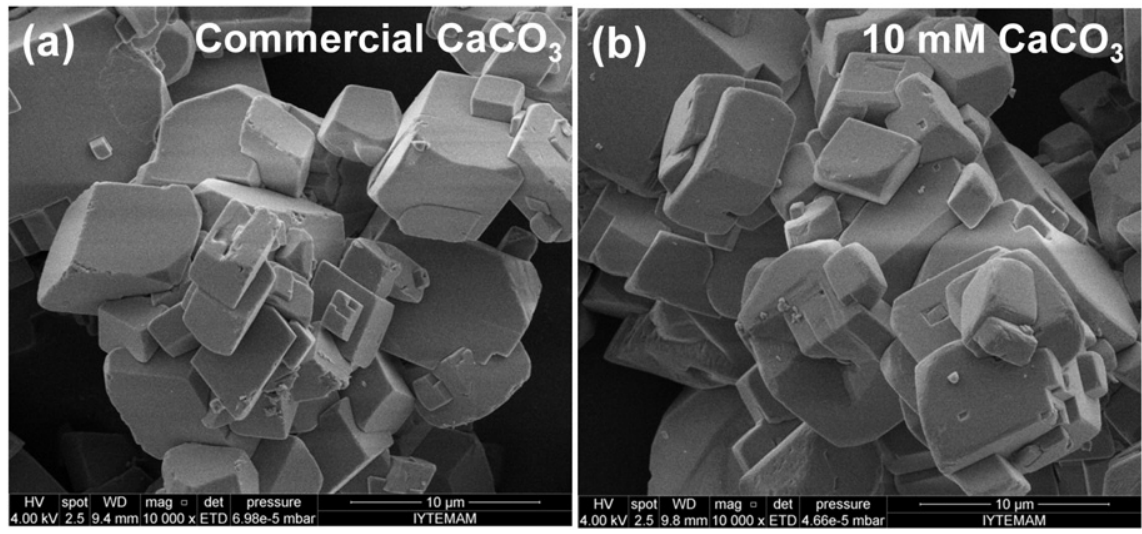

Fig. 9. SEM images of (a) as-received commercial $\mathrm{CaCO}_{3}$ and (b) from $10 \mathrm{mM}$ of $\mathrm{CaCO}_{3}$ slurry. 


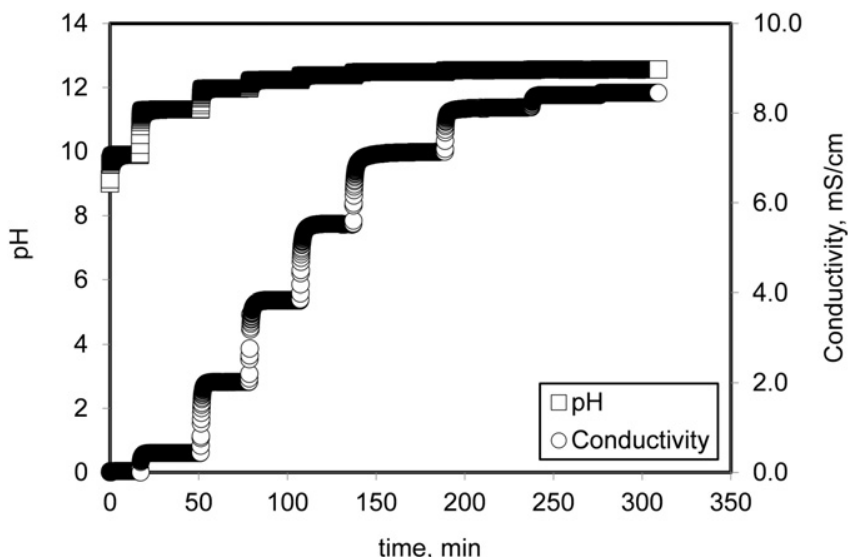

Fig. 11. Change of $\mathrm{pH}$ and conductivity in the presence of various $\mathrm{Ca}(\mathrm{OH})_{2}$ addition into $10 \mathrm{mM}$ of $\mathrm{CaCO}_{3}$ slurry.

crystals in the solution according to Eqs. (14) and (15) (Chibowski et al., 2003b; Holysz et al., 2003; Moulin and Roques, 2003).

$\mathrm{Ca}^{++}+\mathrm{HCO}_{3}{ }^{-} \rightleftharpoons \mathrm{CaHCO}_{3}{ }^{+} \quad \mathrm{pK}_{\mathrm{a}}=+0.82$

$\mathrm{CaHCO}_{3}{ }^{+} \rightleftharpoons \mathrm{CaCO}_{3}(\mathrm{aq})+\mathrm{H}^{+} \quad \mathrm{pK}_{\mathrm{a}}=-7.90$

Fig. 8 shows the $\mathrm{pH}$ and conductivity values at different concentrations of $\mathrm{CaCO}_{3}$. As shown in the figure, the conductivity values showed a linear increase at concentrations up to almost $0.13 \mathrm{mM}$ of $\mathrm{CaCO}_{3}$ solution. The changes in conductivity and $\mathrm{pH}$ values were insignificant for the subsequent $\mathrm{CaCO}_{3}$ powder addition up to a $100 \mathrm{mM}$. Therefore, the $\mathrm{CaCO}_{3}$ solution became slurry at $\mathrm{CaCO}_{3}$ concentrations higher than $0.13 \mathrm{mM}$.
Fig. 9 shows the $\mathrm{SEM}$ images of as-received commercial $\mathrm{CaCO}_{3}$ particles and $\mathrm{CaCO}_{3}$ particles obtained from the $10 \mathrm{mM}$ of $\mathrm{CaCO}_{3}$ slurry. As shown in the images, the commercial $\mathrm{CaCO}_{3}$ particles are in aggregated form with a cubical shape with sizes from about $2 \mu \mathrm{m}$ to $10 \mu \mathrm{m}$ each. Neither the size nor their surface morphologies of the $\mathrm{CaCO}_{3}$ particles were affected when they added into water for dissolution.

Fig. 10 shows the measured zeta potential values and average particle sizes in the $\mathrm{CaCO}_{3}$ solution at different concentrations. As shown in the figure, the zeta potential was about $-3 \mathrm{mV}$ and the average particle size was about $2 \mu \mathrm{m}$ for the freshly dissolved $\mathrm{CaCO}_{3}$ particles at concentration of about $1 \mathrm{mM}$. With the subsequent addition of $\mathrm{CaCO}_{3}$ powder into the already ionized solution, it is seen that while the zeta potential decreased to about $-11 \mathrm{mV}$, the average particle size remained the same at about $4 \mu \mathrm{m}$. We attribute the subsequent increase in zeta potential to $\mathrm{Ca}^{++}$and $\mathrm{CO}_{3}^{=}$ions formed in the solution upon dissolution of $\mathrm{CaCO}_{3}$ particles. At high $\mathrm{pH}, \mathrm{Ca}^{++}$and $\mathrm{OH}^{-}$ions form complexes leaving $\mathrm{CO}_{3}=$ ions in the solution alone, and therefore, increasing the concentration of the $\mathrm{CO}_{3}=$ ions in the slurry. The remained $\mathrm{CO}_{3}=$ ions then proceed into formation of carbonate buffer and adsorb onto the surface of $\mathrm{CaCO}_{3}$ particles resulting in a net negative charge for the $\mathrm{CaCO}_{3}$ particles. The measured zeta potential of $-11 \mathrm{mV}$ is in a very good agreement with the literature data (Chibowski et al., 2003b; Moulin and Roques, 2003).

\subsection{Dissolution of $\mathrm{Ca}(\mathrm{OH})_{2}$ in $10 \mathrm{mM}$ of $\mathrm{CaCO}_{3}$ slurry}

The dissolution of $\mathrm{Ca}(\mathrm{OH})_{2}$ powder in $10 \mathrm{mM}$ of $\mathrm{CaCO}_{3}$ slurry was studied. Initially, a powder of commercial $\mathrm{CaCO}_{3}$ was added into ultrapure water to prepare $10 \mathrm{mM}$ of $\mathrm{CaCO}_{3}$ slurry. Since the dissolution of $\mathrm{CaCO}_{3}$ in ultrapure water is very low, about $0.13 \mathrm{mM}$, only small amount of $\mathrm{CaCO}_{3}$ ionized in the slurry, resulting in a $\mathrm{pH}$ value of about 9.3 and a conductivity value of about close to zero. Fig. 11 shows $\mathrm{pH}$ and conductivity values during the addition of $\mathrm{Ca}(\mathrm{OH})_{2}$ powders into a $10 \mathrm{mM}$ of $\mathrm{CaCO}_{3}$ slurry. As shown in the figure, $\mathrm{pH}$ and conductivity values
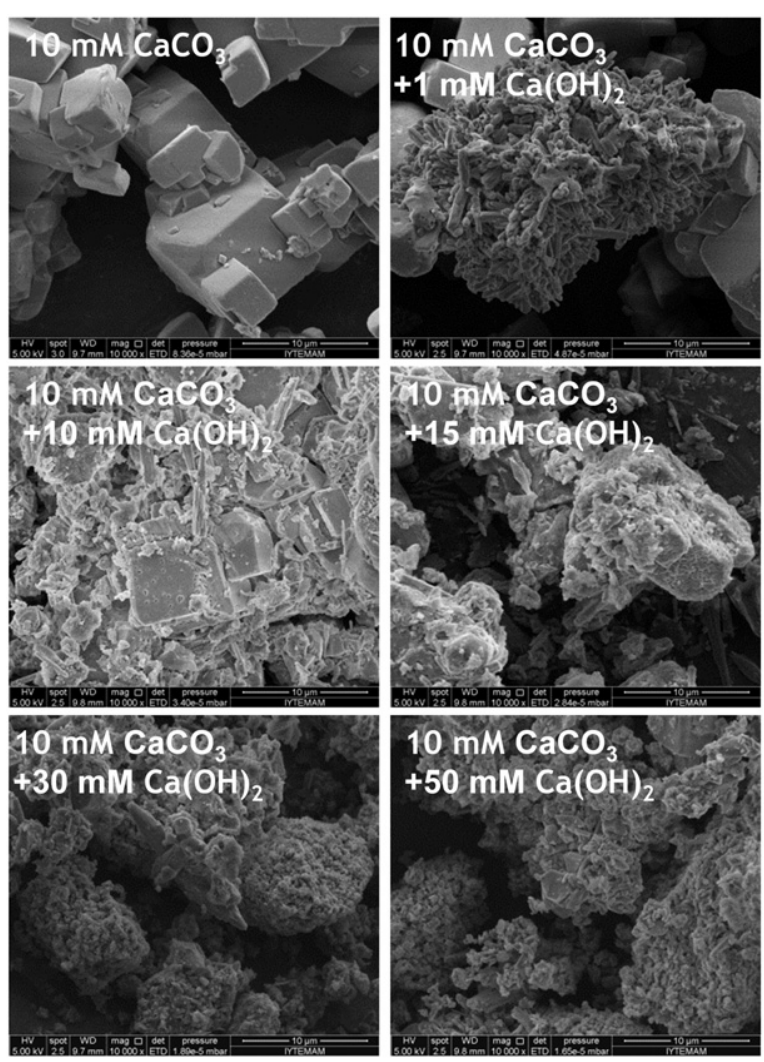
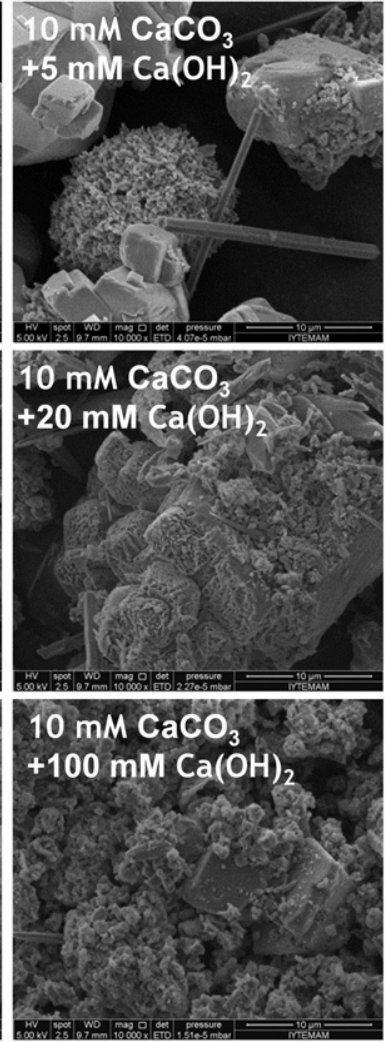

Fig. 12. SEM images of particles during $\mathrm{Ca}(\mathrm{OH})_{2}$ addition into $10 \mathrm{mM}$ of $\mathrm{CaCO}_{3}$ slurry. 
increased with the subsequent addition of $\mathrm{Ca}(\mathrm{OH})_{2}$ powders into the $10 \mathrm{mM}$ of $\mathrm{CaCO}_{3}$ slurry up to its saturation concentration of about $18 \mathrm{mM}$, similar to the pure $\mathrm{Ca}(\mathrm{OH})_{2}$ dissolution in ultrapure water.

Fig. 12 shows the SEM images of the samples taken from each suspension during the addition of $\mathrm{Ca}(\mathrm{OH})_{2}$ powders in $10 \mathrm{mM}$ of $\mathrm{CaCO}_{3}$ slurry. As seen, the surfaces of the commercial $\mathrm{CaCO}_{3}$ particles are so faultless with sizes varying from $2 \mu \mathrm{m}$ to more than $10 \mu \mathrm{m}$ in the suspension. The added $\mathrm{Ca}(\mathrm{OH})_{2}$ powder into the solution was expected to fully dissolve at concentrations lower than its solubility limit of about $18 \mathrm{mM}$. Although the surfaces of some particles were not affected significantly by the addition of very small amount of $\mathrm{Ca}(\mathrm{OH})_{2}$ of $1 \mathrm{mM}$ and $5 \mathrm{mM}$, it is clearly seen from the SEM images that some newly synthesized particles exist in the solution and they were in nano-sizes, either in aggregated form in the solution or in precipitated form on the surfaces of the $\mathrm{CaCO}_{3}$ particles. We observed that the surfaces of the $\mathrm{CaCO}_{3}$ particles were highly affected by the further $\mathrm{Ca}(\mathrm{OH})_{2}$ additions. It can be seen from the images that the surfaces of the $\mathrm{CaCO}_{3}$ particles deformed or eroded in the presence of excess $\mathrm{Ca}(\mathrm{OH})_{2}$. We think that the observed deformations on the surface of the $\mathrm{CaCO}_{3}$ particles are the consequence of $\mathrm{Ca}^{++}$and $\mathrm{CO}_{3}=$ ions dissociating from the particle surface and subsequently converting into newly synthesized nano- $\mathrm{CaCO}_{3}$ particles. A surface deformation of the $\mathrm{CaCO}_{3}$ particles and the coverage of $\mathrm{CaCO}_{3}$ particles with the potential determining $\mathrm{Ca}^{++}, \mathrm{CO}_{3}=$, and $\mathrm{OH}^{-}$ions could influence the zeta potential and stability of the $\mathrm{CaCO}_{3}$ particles in the $\mathrm{Ca}(\mathrm{OH})_{2}$ solution.

Fig. 13 shows the zeta potential and average particle sizes during $\mathrm{Ca}(\mathrm{OH})_{2}$ addition into $10 \mathrm{mM}$ of $\mathrm{CaCO}_{3}$. The zeta potential of $10 \mathrm{mM}$ $\mathrm{CaCO}_{3}$ slurry (with zero $\mathrm{Ca}(\mathrm{OH})_{2}$ addition) was measured to be about $-2 \mathrm{mV}$ and the particle size was about $3 \mu \mathrm{m}$, which is in very good agreement with the literature (Chibowski et al., 2003b). The zeta potential and the particle size were measured to be $+24 \mathrm{mV}$ and about $1 \mu \mathrm{m}$, respectively, upon addition of $1 \mathrm{mM}$ of $\mathrm{Ca}(\mathrm{OH})_{2}$ solution. Further addition of $\mathrm{Ca}(\mathrm{OH})_{2}$ powder into $10 \mathrm{mM}$ of the $\mathrm{CaCO}_{3}$ slurry caused the measured zeta potential values to increase up to about $+40 \mathrm{mV}$ and the particle sizes to decrease down to about $300 \mathrm{~nm}$ up to its solubility limit of about $18 \mathrm{mM}$. The decrease in particle size from $3 \mu \mathrm{m}$ to $300 \mathrm{~nm}$ and increase in the zeta potential from $-2 \mathrm{mV}$ to $+40 \mathrm{mV}$ with addition of the $\mathrm{Ca}(\mathrm{OH})_{2}$ powder into the $\mathrm{CaCO}_{3}$ slurry clearly indicated that there was an increase in the population of the newly synthesized nano- $\mathrm{CaCO}_{3}$ particles in the solution and these newly formed particles were more stable in the solution. We think that the measured particle size and zeta potential values were belong to the newly synthesized particles, because bigger particles were expected to settle faster than the smaller particles (Molva, 2011). Above the saturation limit of the $\mathrm{Ca}(\mathrm{OH})_{2}$, the particles exhibited an increase in size up to about $4 \mu \mathrm{m}$ most probably due to precipitation of nano-particles on the $\mathrm{CaCO}_{3}$ surfaces and aggregation of undissolved $\mathrm{Ca}(\mathrm{OH})_{2}$ particles in the solution as shown in the images in Fig. 12. But from the Fig. 13, it is clearly seen that at around the solubility limit of $\mathrm{Ca}(\mathrm{OH})_{2}$, the zeta potential of $\mathrm{CaCO}_{3}$ particles is not only positive in the $\mathrm{Ca}(\mathrm{OH})_{2}$ solution but also its value is greater than $+30 \mathrm{mV}$ producing stable $\mathrm{CaCO}_{3}$ particles in the $\mathrm{Ca}(\mathrm{OH})_{2}$ solution.

\subsection{Dissolution of $\mathrm{CaCO}_{3}$ in $10 \mathrm{mM}$ of $\mathrm{Ca}(\mathrm{OH})_{2}$ solution}

A $10 \mathrm{mM} \mathrm{Ca}(\mathrm{OH})_{2}$ solution was prepared in ultrapure water and subsequently different amounts of $\mathrm{CaCO}_{3}$ powder was added into the $10 \mathrm{mM}$ of $\mathrm{Ca}(\mathrm{OH})_{2}$ solution. Fig. 14 shows $\mathrm{pH}$ and conductivity values during the $\mathrm{CaCO}_{3}$ addition in $10 \mathrm{mM}$ of $\mathrm{Ca}(\mathrm{OH})_{2}$ solution. As shown in the figure, a pH of about 12 and conductivity of about $4.2 \mathrm{mS} / \mathrm{cm}$ were measured for the $10 \mathrm{mM}$ of $\mathrm{Ca}(\mathrm{OH})_{2}$ solution and both values remained unchanged even though different amounts of $\mathrm{CaCO}_{3}$ powders were added subsequently.

The SEM images of particles during addition of commercial $\mathrm{CaCO}_{3}$ powder into the $10 \mathrm{mM}$ of $\mathrm{Ca}(\mathrm{OH})_{2}$ solution are shown in Fig. 15. Inert particles were obtained from the centrifugation of the $10 \mathrm{mM}$ of

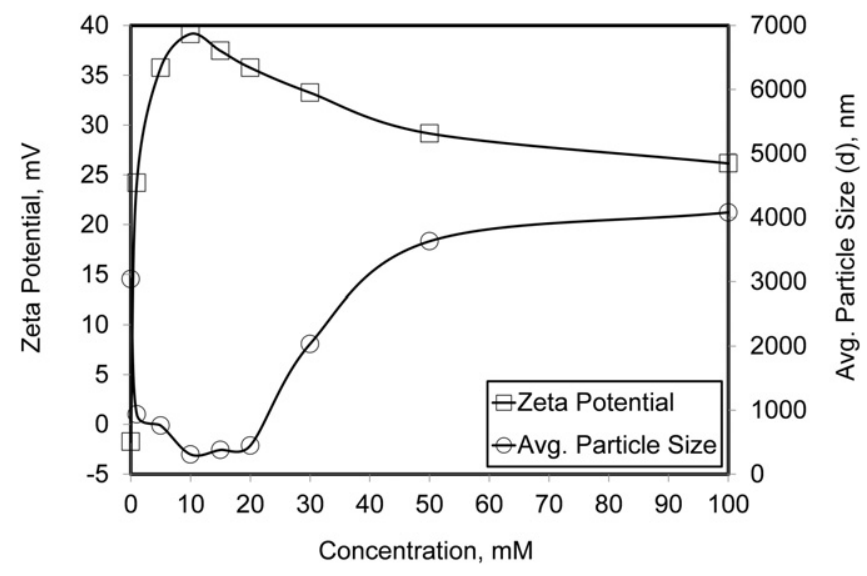

Fig. 13. Change of zeta potential and average particle size in the presence of various $\mathrm{Ca}(\mathrm{OH})_{2}$ addition into $10 \mathrm{mM} \mathrm{CaCO}_{3}$.

$\mathrm{Ca}(\mathrm{OH})_{2}$ solution and observed to be mostly needle-like aragonite type $\mathrm{CaCO}_{3}$ particles. Upon addition of commercial $\mathrm{CaCO}_{3}$ particles, newly synthesized nano-particles were observed to form in the solution with different morphologies. The deformations or erosions on the surfaces of the $\mathrm{CaCO}_{3}$ particles can also be discerned in the images. The surface coverage of the particles and the newly formed nano- $\mathrm{CaCO}_{3}$ particles could affect the zeta potential and the measured particle sizes in the solution.

The measured zeta potential and average particle sizes for the $\mathrm{CaCO}_{3}$ particles in $10 \mathrm{mM}$ of $\mathrm{Ca}(\mathrm{OH})_{2}$ solution are illustrated in Fig. 16. As shown in the figure, the zeta potential and average particle size of the $10 \mathrm{mM}$ of $\mathrm{Ca}(\mathrm{OH})_{2}$ solution were measured to be $+38 \mathrm{mV}$ and $350 \mathrm{~nm}$, respectively. We surmise that these measured values would belong to the impurity $\mathrm{CaCO}_{3}$ particles and newly synthesized nano$\mathrm{CaCO}_{3}$ particles suspended in the $10 \mathrm{mM}$ of $\mathrm{Ca}(\mathrm{OH})_{2}$ solution. Upon addition of $\mathrm{CaCO}_{3}$ particles into $10 \mathrm{mM}$ of $\mathrm{Ca}(\mathrm{OH})_{2}$ solution in a stepwise fashion, while the zeta potential values decreased almost linearly down to $+31 \mathrm{mV}$, average particle sizes did not exhibit a significant change. When the added $\mathrm{CaCO}_{3}$ powder concentration was increased to $30 \mathrm{mM}$ and higher, it was observed that the zeta potential values exhibited a sudden increase from $+31 \mathrm{mV}$ to about $+47 \mathrm{mV}$ and the average particle sizes exhibited a size less than $1 \mu \mathrm{m}$. We believe that the net positive charge on the $\mathrm{CaCO}_{3}$ surface is resulting from the $\mathrm{Ca}^{+}$sites (Chibowski et al., 2003c), and thus the excess $\mathrm{Ca}^{++}$ions inhibit aggregation between particles, leading to formation of nano- $\mathrm{CaCO}_{3}$ particles. As shown in the figure, the zeta potential of the $\mathrm{CaCO}_{3}$ particles in $\mathrm{Ca}(\mathrm{OH})_{2}$ solution is more than $+30 \mathrm{mV}$, suggesting that $\mathrm{CaCO}_{3}$ particles are stable in the $\mathrm{Ca}(\mathrm{OH})_{2}$ solution. This finding on the stability of newly

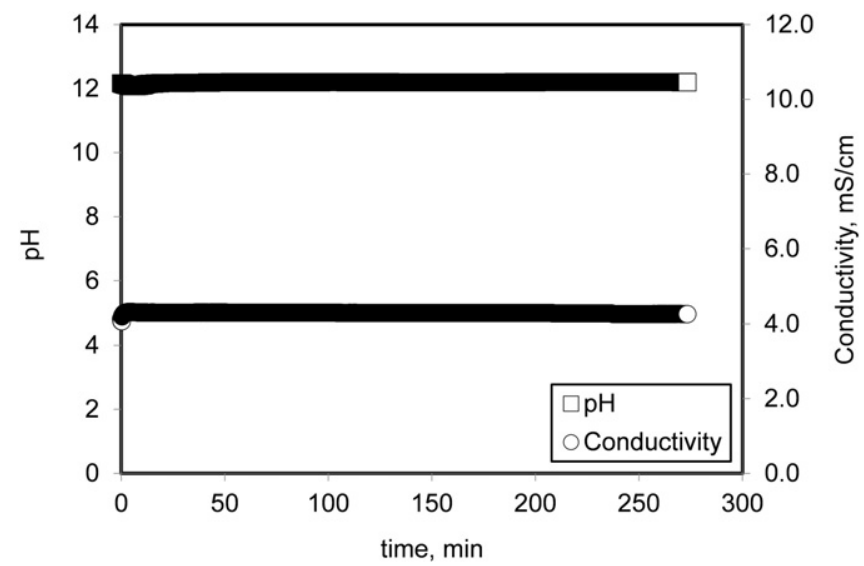

Fig. 14. $\mathrm{pH}$ and conductivity values during $\mathrm{CaCO}_{3}$ addition in $10 \mathrm{mM} \mathrm{Ca}(\mathrm{OH})_{2}$ solution 


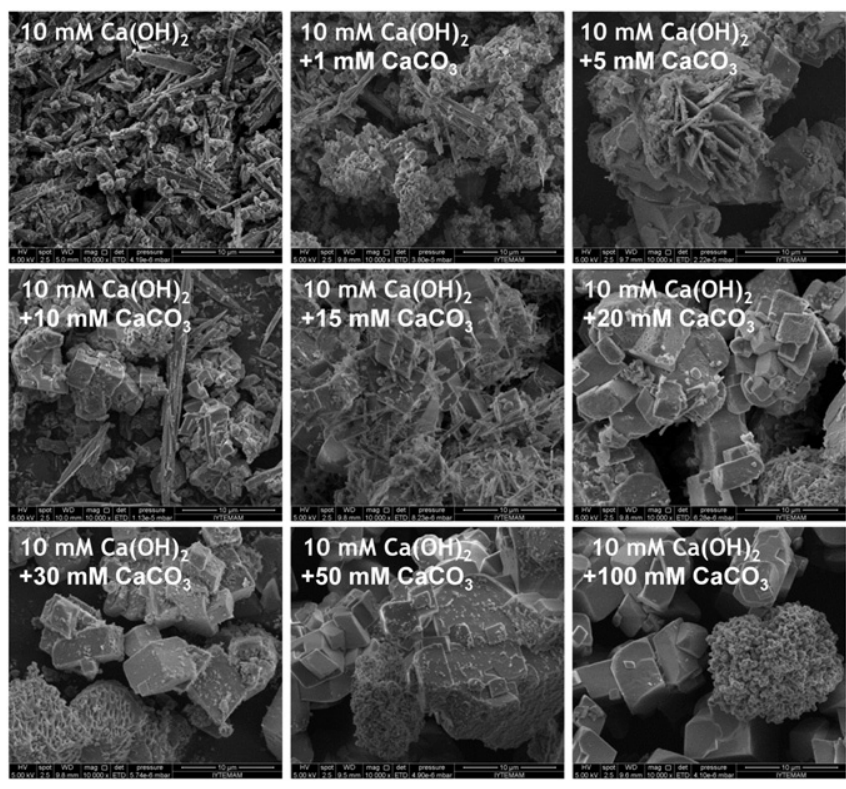

Fig. 15. SEM images of $\mathrm{CaCO}_{3}$ addition into $\left.10 \mathrm{mM} \mathrm{Ca(OH}\right)_{2}$ solution.

formed nano- $\mathrm{CaCO}_{3}$ particles in the $\mathrm{Ca}(\mathrm{OH})_{2}$ solution is important for the aggregation and growth of $\mathrm{CaCO}_{3}$ on the surfaces for scale formation as well as the production of stable nano- $\mathrm{CaCO}_{3}$ particles.

\section{Conclusions}

Calcium carbonate is one of the principal constituents of hard scale formed in many industrial and heating installations. One of the causes for scale formation is the surface charge which is one of the most important parameters in dissolution and precipitation of $\mathrm{CaCO}_{3}$. In order to understand the phenomena occurring in $\mathrm{CaCO}_{3}$ crystallization in $\mathrm{Ca}(\mathrm{OH})_{2}$ as in the carbonization method, the zeta potential values of $\mathrm{CaCO}_{3}$ particles in $\mathrm{Ca}(\mathrm{OH})_{2}$ solution were investigated. The solubility for $\mathrm{CaCO}_{3}$ was measured to be about $0.13 \mathrm{mM}$, which was lower compared to the solubility for $\mathrm{Ca}(\mathrm{OH})_{2}$ measured to be about $18 \mathrm{mM}$ in ultrapure water. The dissolution of both $\mathrm{CaCO}_{3}$ and $\mathrm{Ca}(\mathrm{OH})_{2}$ powders produced ions such as $\mathrm{Ca}^{++}, \mathrm{CO}_{3}=\mathrm{OH}^{-}$, and $\mathrm{CaOH}^{+}$as well as newly synthesized nano- $\mathrm{CaCO}_{3}$ particles in the solution. The zeta potential values for the particles were measured to be always positive in $\mathrm{Ca}(\mathrm{OH})_{2}$ solution due to an imbalance between $\mathrm{Ca}^{++}$and $\mathrm{CO}_{3}=$ ions in solution so called the potential determining ions (PDI). It was concluded that the zeta potential of $\mathrm{CaCO}_{3}$ is more than $+30 \mathrm{mV}$ in the $\mathrm{Ca}(\mathrm{OH})_{2}$ solution and therefore

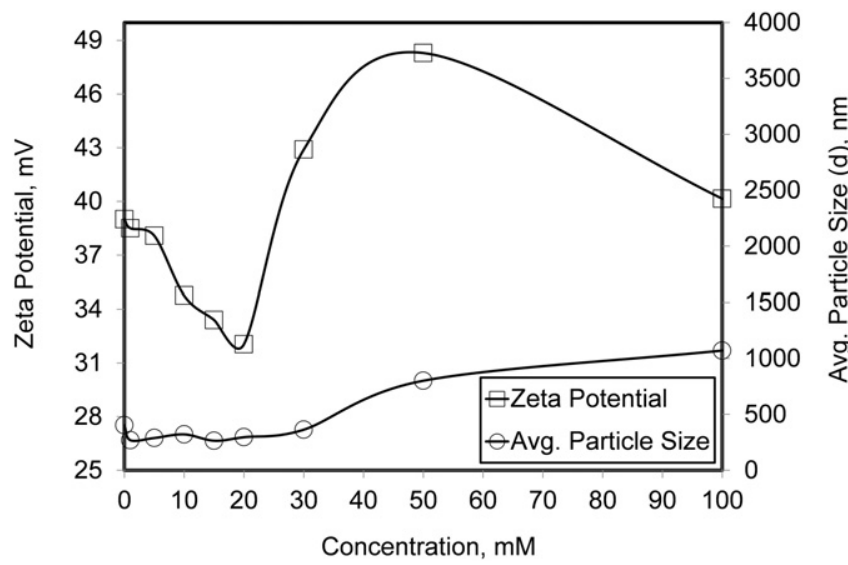

Fig. 16. Zeta potential and average particle size values during addition of $\mathrm{CaCO}_{3}$ into a $10 \mathrm{mM} \mathrm{Ca}(\mathrm{OH})_{2}$ solution. they are more stable. Hence, aggregation and growth of $\mathrm{CaCO}_{3}$ could be managed and nano- $\mathrm{CaCO}_{3}$ particles produced in $\mathrm{Ca}(\mathrm{OH})_{2}$ solution.

\section{Acknowledgment}

The Scientific and Technological Research Council of Turkey (TUBITAK) is highly appreciated for the research grant with the project number 110M104.

\section{References}

Agnihotri, R., Mahuli, S.K., Chauk, S.S., Fan, L.S., 1999. Influence of surface modifiers on the structure of precipitated calcium carbonate. Ind. Eng. Chem. Res. 38, 2283-2291.

Bots, P., Benning, L.G., Rodriguez-Blanco, J.-D., Roncal-Herrero, T., Shaw, S., 2012. Mechanistic insights into the crystallization of amorphous calcium carbonate (ACC). Cryst Growth Des. 12, 3806-3814.

Burns, J.R., Jachuck, J.J., 2005. Monitoring of $\mathrm{CaCO}_{3}$ production on a spinning disc reactor using conductivity measurements. AICHE J. 51, 1497-1507.

Carmona, J.G., Morales, J.G., Rodriguez-Clemente, R., 2003a. Rhombohedral-scalenohedral calcite transition produced by adjusting the solution electrical conductivity in the system $\mathrm{Ca}(\mathrm{OH})(2)-\mathrm{CO}_{2}-\mathrm{H}_{2} \mathrm{O}$. J. Colloid Interface Sci. 261, 434-440.

Carmona, J.G., Morales, J.G., Sainz, J.F., Clemente, R.R., 2003b. Morphological characteristics and aggregation of calcite crystals obtained by bubbling $\mathrm{CO}_{2}$ through a $\mathrm{Ca}(\mathrm{OH}) 2$ suspension in the presence of additives. Powder Technol. 130, 307-315.

Carmona, J.G., Morales, J.G., Sainz, J.F., Loste, E., Clemente, R.R., 2004. The mechanism of precipitation of chain-like calcite. J. Cryst. Growth 262, 479-489.

Chen, J.F., Wang, Y.H., Guo, F., Wang, X.M., Zheng, C., 2000. Synthesis of nanoparticles with novel technology: high-gravity reactive precipitation. Ind. Eng. Chem. Res. 39, 948-954.

Chibowski, E., Hołysz, L., Szcześ, A., Chibowski, M., 2003a. Precipitation of calcium carbonate from magnetically treated sodium carbonate solution. Colloids Surf. A Physicochem. Eng. Asp. 225, 63-73.

Chibowski, E., Hotysz, L., Szczes, A., 2003b. Time dependent changes in zeta potential of freshly precipitated calcium carbonate. Colloid Surface A 222, 41-54.

Chibowski, E., Hotysz, L., Szcześ, A., 2003c. Time dependent changes in zeta potential of freshly precipitated calcium carbonate. Colloids Surf. A Physicochem. Eng. Asp. 222 41-54.

García-Carmona, J., Gómez-Morales, J., Fraile-Sainz, J., Rodríguez-Clemente, R., 2003. Morphological characteristics and aggregation of calcite crystals obtained by bubbling $\mathrm{CO}_{2}$ through a $\mathrm{Ca}(\mathrm{OH}) 2$ suspension in the presence of additives. Powder Technol. 130, 307-315.

Gebauer, D., Volkel, A., Colfen, H., 2008. Stable prenucleation calcium carbonate clusters. Science 322, 1819-1822.

Gunasekaran, S., Anbalagan, G., 2008. Spectroscopic study of phase transitions in natural calcite mineral. Spectrochim. Acta A 69, 1246-1251.

Holysz, L., Chibowski, E., Szczes, A., 2003. Influence of impurity ions and magnetic field on the properties of freshly precipitated calcium carbonate. Water Res. 37, 3351-3360.

Johannsen, K., Rademacher, S., 1999. Modelling the kinetics of calcium hydroxide dissolution in water. Acta Hydrochim. Hydrobiol. 27, 72-78.

Jung, W.M., Kang, S.H., Kim, W.-S., Choi, C.K., 2000. Particle morphology of calcium carbonate precipitated by gas-liquid reaction in a Couette-Taylor reactor. Chem. Eng. Sci. 55, 733-747.

Kellermeier, M., Gebauer, D., Melero-Garcia, E., Drechsler, M., Talmon, Y., Kienle, L., Colfen, H., Garcia-Ruiz, J.M., Kunz, W., 2012. Colloidal stabilization of calcium carbonate prenucleation clusters with silica. Adv. Funct Mater. 22 4301-4311.

Kes, M., 2007. Determination of the Particle Interactions - Rheology-Surface Roughness Relationship for Dental Ceramics Department of Chemistry. Izmir Institute of Technology, Izmir, p. 111.

Kilic, S., Ozdemir, E., 2015. Toward synthesis of nanoCaCO 3 . J. Cryst. Growth (submitted for publication)

Kitamura, M., Konno, H., Yasui, A., Masuoka, H., 2002. Controlling factors and mechanism of reactive crystallization of calcium carbonate polymorphs from calcium hydroxide suspensions. J. Cryst. Growth 236, 323-332.

Lide, D., 1995. CRC Handbook of Chemistry and Physics. 75th ed. CRC Press, Boca Raton.

Lin, Y., Chen, H.B., Chan, C.M., Wu, J.S., 2008. High impact toughness polypropylene/ $\mathrm{CaCO}_{3}$ nanocomposites and the toughening mechanism. Macromolecules 41, 9204-9213.

Liu, Q., Wang, Q., Xiang, L., 2008. Influence of poly acrylic acid on the dispersion of calcite nano-particles. Appl. Surf. Sci. 254, 7104-7108.

Molva, M., 2011. Production of $\mathrm{Nano}^{\mathrm{CaCO}_{3}}$ by Carbonization Route (Master of Science thesis) Izmir Institude of Technology.

Montes-Hernandez, G., Fernández-Martínez, A., Charlet, L., Tisserand, D., Renard, F., 2008. Textural properties of synthetic nano-calcite produced by hydrothermal carbonation of calcium hydroxide. J. Cryst. Growth 310, 2946-2953.

Moulin, P., Roques, H., 2003. Zeta potential measurement of calcium carbonate. J. Colloid Interface Sci. 261, 115-126.

Perry, R., Green, D., Maloney, J., 1984. Perry's Chemical Engineers' Handbook. sixth ed. McGraw-Hill, New York.

Pouget, E.M., Bomans, P.H.H., Goos, J.A.C.M., Frederik, P.M., de With, G., Sommerdijk, N.A.J.M., 2009. The initial stages of template-controlled $\mathrm{CaCO}_{3}$ formation revealed by Cryo-TEM. Science 323, 1455-1458

Pourchet, S., Pochard, I., Brunel, F., Perrey, D., 2013. Chemistry of the calcite/water interface: influence of sulfate ions and consequences in terms of cohesion forces. Cem. Concr. Res. 52, 22-30. 
Rodriguez-Blanco, J.D., Shaw, S., Benning, L.G., 2011. The kinetics and mechanisms of amorphous calcium carbonate (ACC) crystallization to calcite, via vaterite. Nanoscale 3, 265-271.

Seo, K.S., Han, C., Wee, J.H., Park, J.K., Ahn, J.W., 2005. Synthesis of calcium carbonate in a pure ethanol and aqueous ethanol solution as the solvent. J. Cryst. Growth 276 680-687.

Sheng, Y., Zhou, B., Zhao, J.Z., Tao, N., Yu, K.F., Tian, Y.M., Wang, Z.C., 2004. Influence of octadecyl dihydrogen phosphate on the formation of active super-fine calcium carbonate. J. Colloid Interface Sci. 272, 326-329.

Stepkowska, E.T., Perez-Rodriguez, J.L., Sayagues, M.J., Martinez-Blanes, J.M., 2003. Calcite, vaterite and aragonite forming on cement hydration from liquid and gaseous phase. J. Therm. Anal. Calorim. 73, 247-269.

Tai, C.Y., Chen, F.B., 1998. Polymorphism of $\mathrm{CaCO}_{3}$ precipitated in a constant-composition environment. AICHE J. 44, 1790-1798.
Ukrainczyk, M., Kontrec, J., Babic-Ivancic, V., Brecevic, L., Kralj, D., 2007. Experimental design approach to calcium carbonate precipitation in a semicontinuous process. Powder Technol. 171, 192-199.

Wang, J., Keener, T.C., Li, G., Khang, S.J., 1998. The dissolution rate of $\mathrm{Ca}(\mathrm{OH})(2)$ in aqueous solutions. Chem. Eng. Commun. 169, 167-184.

Xu, A.W., Ma, Y.R., Colfen, H., 2007. Biomimetic mineralization. J. Mater. Chem. 17, 415-449.

Yan, G.W., Huang, J.H., Zhang, J.F., Qian, C.J., 2008. Aggregation of hollow $\mathrm{CaCO}_{3}$ spheres by calcite nanoflakes. Mater. Res. Bull. 43, 2069-2077.

Yuan, P.Q., Cheng, Z.M., Zhou, Z.M., Yuan, W.K., Semiat, R., 2008. Zeta potential on the anti-scalant modified sub-micro calcite surface. Colloids Surf. A 328, 60-66. 